\title{
MENINGKATKAN HASIL BELAJAR MATEMATIKA SISWA MELALUI MODEL PEMBELAJARAN ROPES (REVIEW, OVERVIEW, PRESENTATION, EXERCISE, SUMMARY)
}

\author{
Tammara Yuffa ${ }^{1}$, Lenny Kurniati ${ }^{2}$, Arie Wahyuni ${ }^{3}$ \\ tammarayuffa@gmail.com \\ ${ }^{1,2,3}$ Universitas Ivet
}

\begin{abstract}
The learning mathematics to students will be easier to master and understand the concept of linear equation material of one variable through the ROPES learning model. This study aims to determine that with the application of ROPES learning model on linear equation material of one variable can improve students' learning result, students' activities, and teachers' performance. The subject of this study is the students of class VII B in the first semester at MTS Matholiul Ulum Banjaragung, Bangsri, Jepara in 2019/2020. Instruments were tests sheet and questionnaires. The type of this research is a classroom action research with two cycles where each cycle there are two meetings. The stages include planning, implementation, observation and reflection. The results showed an increase in student's ability to solve problems about linear equations of one variable. Based on reflection results in cycles 1 and II, it showed: 1) Students' learning result is increased, in the cycle I the average result was 64.90 and in cycle II reached 73.18. 2) In cycle I of the first meeting was $59.67 \%$ categorized 'enough'. The second was $6601 \%$ categorized 'good', and in the cycle II reached $81.15 \%$ categorized 'very good'. 3) Increased teacher performance in the first cycle was $60 \%$ categorized medium, the second meeting reached $70 \%$ categorized high, and in cycle II reached $80 \%$ categorized very high.
\end{abstract}

Kata kunci: Mathematical Learning Result, ROPES Learning Model.

\begin{abstract}
Abstrak
Pembelajaran matematika terhadap siswa akan lebih mudah dapat menguasai dan memahami konsep materi Persamaan linier satu variabel dengan membelajarkan model pembelajaran ROPES. Penelitian ini bertujuan untuk mengetahui bahwa dengan penerapan model pembelajaran ROPES pada materi Persamaan linier satu variabel yaitu dapat meningkatkan hasil belajar siswa, aktifitas siswa, dan kinerja guru. Subjek penelitian ini adalah siswa kelas VII B semester gasal MTs Matholiul Ulum Banjaragung Bangsri Jepara tahun pelajaran 2019/2020. Instrumen yang digunakan lembar tes dan angket. Jenis penelitian ini merupakan penelitian tindakan kelas yang didesain dalam dua siklus dimana tiap siklus ada dua kali pertemuan. Tahapan tindakan penelitian kelas meliputi perencanaan, pelaksanaan, pengamatan dan refleksi. Dari hasil penelitian menunjukkan adanya peningkatan kemampuan siswa dalam menyelesaikan masalah tentang Persamaan linear satu variabel. Bedasarkan hasil refleksi pada siklus 1 dan II dihasilkan antara lain: 1) Meningkatnya hasil belajar siswa, pada silus I rata-rata hasil belajar siswa 64,90 dan pada siklus II mencapai 73,18. 2) Meningkatnya keaktifan siswa pada siklus I pertemuan pertama $59,67 \%$ dikategorikan cukup, pertemuan kedua 66,01\% dikategorikan baik, dan pada siklus II mencapai $81,15 \%$ dikategorikan sangat baik. 3) Meningkatnya kinerja guru pada siklus I pertemuan pertama mencapai $60 \%$ dikategorikan sedang, pertemuan kedua mencapai $70 \%$ dikategorikan tinggi, dan pada siklus II mencapai $80 \%$ dikategorikan sangat tinggi.
\end{abstract}


Kata kunci: Hasil Belajar Matematika,Model Pembelajaran ROPES.

\section{ARTICLE HISTORY:}

Received: 21 Maret 2020, Revised: 1 April 2020,

Accepted: 4 April 2020, Onlinefirst: 11 April 2020

\section{PENDAHULUAN}

Sumber daya manusia (SDM) menjadi faktor pendidikan. Pendidikan memerlukan SDM yang berkualitas untuk melaksanakan perannya dalam memenuhi kebutuhan pendidikan masyarakat, karena pendidikan diyakini sebagai salah satu bidang yang memiliki peran penting dalam pembangunan suatu bangsa. Perkembangan pada era globalisasi sekarang ini menuntut adanya sumber daya manusia yang berkualitas tinggi, dimana hal ini merupakan kunci untuk mencapai tujuan pembangunan (Ningrum, 2009). Menurut Sumitro (2006) menyatakan pendidikan merupakan proses pengembangan dan perilaku manusia secara keseluruhan. Selanjutnya pendidikan berguna untuk mengembangkan nilai-nilai baru dalam menghadapi tantangan umum, teknologi, dan dunia modern.

Proses memperbaiki dan meningkatkan mutu pendidikan seakan tidak pernah berhenti, banyak agenda reformasi yang telah, sedang, dan akan dilaksanakan. Reformasi pendidikan tidak pernah cukup hanya dalam bidang fisik/fasilitasi pendidikan, tetapi juga sarana non-fisik seperti pembangunan kualitas tenaga-tenaga kependidikan yang memiliki pengetahuan atau kemampuan dan keterampilan memanfaatkan fasilitas yang tersedia, cara kerja yang inovatif serta sikap positif terhadap tugas-tugas kependidikan, dan akan lebih bermakna bila diikuti oleh perubahan praktik pembelajaran di dalam dan di luar kelas. Sebagai seorang guru, mengajarkan siswa cara membentuk informasi yang bermakna dan relevan sangat berpengaruh terhadap pemahaman konsep kepada siswa. Hal ini memberikan kesempatan kepada siswa untuk menemukan dan menerapkan gagasannya sendiri. Setiap siswa mempunyai kemampuan dan taraf berpikir yang berbeda, sehingga keterampilan dan keahlian tersebut seorang guru dapat memilih metode yang tepat agar siswa dapat menguasai pelajaran.

Mata pelajaran matematika merupakan mata pelajaran dasar, di sekolah dasar ataupun sekolah menengah. Mempelajari matematika adalah penting karena dalam 
kehidupan sehari-hari, kita tidak boleh mengelak dari aplikasi matematika, bukan itu saja matematika juga mampu mengembangkan kesadaran tentang nilai-nilai yang secara esensial. Menurut Mulyana (2004) mengatakan matematika selain dapat memperluas cakrawala berpikir peserta didik juga mampu mengembangkan kesadaran tentang nilainilai yang secara esensial terdapat didalamnya.

Pembelajaran matematika dalam jenjang sekolah menengah pertama (SMP) ataupun sederajat ditekankan pada penalaran, pemikiran logis dan rasional. Disamping itu juga pemebelajaran matematika di sekolah lanjutan, bertujuan agar siswa dapat memahami pengertian-pengertian matematika. Kebanyakan siswa beranggapan bahwa matematika adalah pelajaran yang sulit sehingga minat belajar siswa menjadi kurang. Karena kurangnya minat belajar siswa mengakibatkan hasil belajar matematika menjadi kurang memuaskan.

Pembelajaran matematika di MTs Matholiul Ulum Banjaragung kecamatan Bangsri kabupaten Jepara khususnya siswa kelas VII B tergolong rendah. Rendahnya hasil belajar matematika di kelas VII B MTs Matholiul Ulum Banjaragung kecamatan Bangsri kabupaten Jepara nampak pada rata rata prestasi belajar siswa masih di bawah KKM (65) yang ditentukan oleh sekolah kami. Berdasarkan tes pada materi menentukan nilai suatu variabel pada persamaan linear satu variabel dari 32 siswa kelas VII B ada 4 siswa (12\%) mendapatkan nilai di atas KKM, sedangkan 28 siswa (88\%) belum mencapai KKM. Selanjutnya hasil rata - rata kelas diperoleh sebesar 59,2.

Adapun masalah yang sering didapati pada proses pembelajaran matematika di MTs matholiul Ulum Banjaragung Bangsri Jepara adalah siswa kurang senang terhadap pelajaran matematika. Kurang memperhatikan guru, siswa kurang terlihat aktif dalam pembelajaran, sehingga siswa masih kesulitan dalam mengerjakan soal-soal matematika terutama pada soal cerita.Salah satunya adalah pada materi PLSV yang diajarkan pada kelas VII semester gasal.Berdasarkan pengamatan guru matematika siswa masih bingung menstransformasikan soal-soal cerita itu ke dalam bentuk aljabar dan juga siswa masih bingung dalam hitung menghitung aljabar.

Hasil pengamatan proses pembelajaran matematika di MTs Matholiul Ulum Banjaragung kecamatan Bangsri kabupaten Jepara menunjukkan bahwa pembelajaran masih berpusat pada guru. Pada saat kegiatan belajar di kelas sebagian besar siswa 
cenderung pasif, siswa juga beranggapan bahwa matematika itu pelajaran yang menakutkan dan membosankan.

Pembelajaran matematika siswa MTs Matholiul Ulum Banajaragung, Bangsri, Jepara masih mengalami kesulitan dan cenderung pasif, yaitu pada pokok bahasan persamaan linear satu variabel.Karena selama ini pembelajaran matematika dilaksanakan dengan metode ceramah. Guru masih mendominasi kelas dan langsung memberitahukan konsep pada siswa sedangkan siswa terlihat pasif hanya menerima konsep jadi yang diberikan tanpa pernah mencari asal usul suatu konsep yang diajarkan. Siswa tidak melakukan sesuatu yang mendorong untuk menemukan konsep secara mandiri, siswa hanya duduk, diam, dan memeperhatikan penejelasan guru dan berlatih akibatnya siswa jadi cepat lupa dengan isi materi yang diterima.

Untuk mengatasi permasalahan tersebut diperlukan model pembelajaran yang tepat agar siswa mampu menguasai dan memahami konsep materi model pembelajaran tersebut yaitu model pembelajaran ROPES (Review, Overview, Presentation, Exercise, Summary), mengharuskan siswa untuk mempersiapkan segala hal yang dibutuhkan sebelum pelajaran dimulai (Review), kemudian memberikan semangat belajar melalui apersepsi pada materi yang akan dipelajari serta menyampaikan secara singkat dengan tujuan siswa bisa menemukan konsep secara mandiri (Overview), setelah melakukan diskusi, hasil berfikir akan dipresentasikan. Setelah itu guru akan memberikan latihan untuk menguikur tingkat kefahaman siswa melalui hasil belajar (Exercise). Setelah selesai melakukan tahapan latihan soal, siswa diharapkan dapat menarik simoulan materi yang benar secara mandiri (Summary).

Berdasarkan rumusan masalah diatas, agar hasil belajar siswa dalam proses pembelajaran matematika pokok bahasan persamaan linear satu variabel dapat meningkat, maka pemecahan masalah dalam penelitian ini berupa penelitian tindakan kelas (PTK) dengan menerapkan model pembelajaran ROPES. Dimana model pembelajaran ROPES merupakan model pembelajaran yang memberikan kesempatan kepada siswa untuk berdiskusi dengan kelompoknya, selain itu juga siswa diminta unutuk mempresentasikan hasil diskusinya dengan tujuan anak berani berbicara didepan kelas dan mengungkapkan ide-ide kreatifnya.

Tujuan penulis dalam penelitian ini adalah mengetahui bahwa model pembelajaran ROPES (Review, Overview, Presentation, exercise, summary) dapat meningkatkan hasil 
belajar siswa, aktifitas siswa, dan kinerja guru pelajaran matematika pada pokok bahasan persamaan linear satu variabel .

\section{METODE PENELITIAN}

Penelitian ini menggunakan penelitian tindakan kelas (Classroom Action Research) karena peneliti bertindak secara langsung dalam penelitian mulai dari awal sampai akhir tindakan. Penelitian tindakan kelas merupakan proses pengkajian masalah pembelajaran di dalam kelas melalui refleksi diri dalam upaya untuk memecahkan masalah dengan cara melakukan berbagai tindakan yang terencana dalam situasi nyata serta menganalisis pengaruh dari perlakuan tersebut (Sanjaya, 2010).

Penelitian tindakan kelas ini dilaksanakan di kelas VII B MTs. Matholiul Ulum Banjaragung Bangsri Jepara.Penelitian tindakan kelas ini dilaksanakan pada bulan Oktober tahun pelajaran 2019/2020 pada semester gasal. Adapun jadwal penelitian tindakan kelas.

Subyek yang diteliti pada penelitian adalah siswa kelas VII B semester gasal di MTs. Matholiul Ulum Banjaragung Bangsri Jepara tahun pelajaran 2019/2020, yang berjumlah 32 siswa yang terdiri dari 12 siswa laki-laki dan 20 siswa perempuan.

Alur dalam penelitian PTK diawali dengan perencanaan tindakan (Planing), penerapan tindakan (Action), mengobservasi dan mengevaluasi (Reflektion), dan solusi sampai perbaikan. Peningkatan yang diharapkan tercapai kriteria keberhasilan. Dalam pembelajaran ROPES nanti peneliti mengelompokan siswa menjadi beberapa kelompok yang terdiri dari 5 sampai 6 anak tanpa membedakan jenis kelamin dan dikelompokan acak, bertujuan supaya siswa yang berkemampuan kurang bisa bergabung dengan yang berkemampuan cukup ataupun tinggi.

Dalam penelitian akan dibuat rancangan tindakan siklus, terdiri dari perencanaan, pelaksanaan, pengamatan, refleksi, dan masing-masing diadakan dua pertemuan.

Berikut pelaksanaan penelitian tindakan kelas (PTK) :

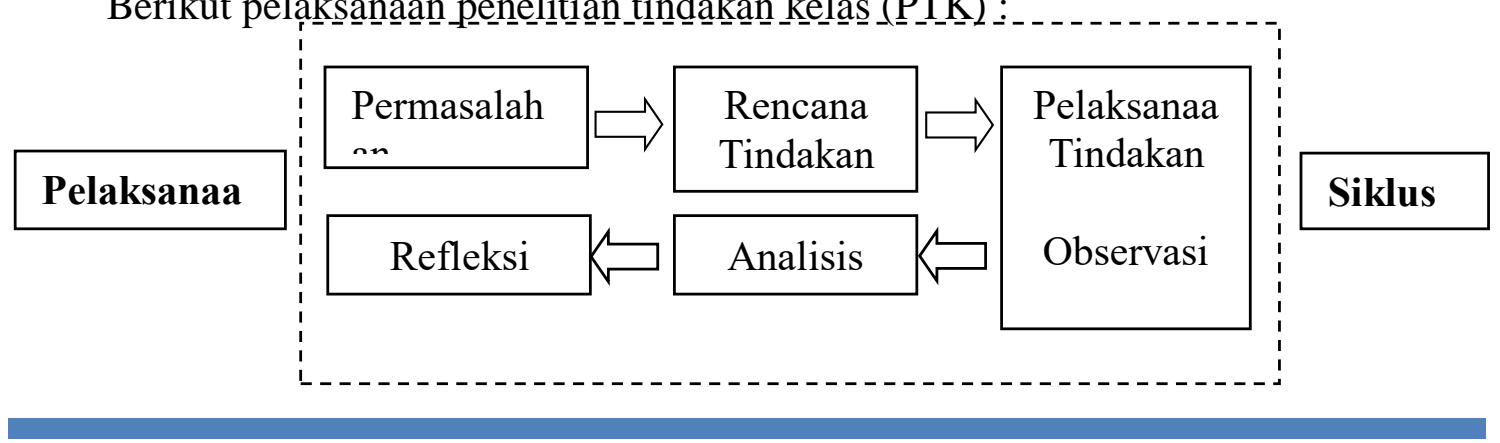


Data yang diambil dalam penelitian ini adalah :

a. Data mengenai kinerja guru dalam pembelajaran yang diambil dengan menggunakan obsevasi.

b. Data aktivitas siswa dan kerjasama dalam kelompok yang diambil dengan menggunakan observasi.

c. Data mengenai hasil belajar siswa yang diambil dengan memberikan tes evaluasi pada setiap akhir siklus.

Data mengenai motivasi dan tanggapan siswa terhadap model pembelajaran ROPES (Review, Overview, Presentation, Exercise, Summary) dengan menggunakan angket refleksi.

Instrumen yang digunakan dalam pengumpulan data adalah sebagai berikut:Lembar Observasi, Tes (Ulangan Harian) dan Angket.

Data mengenai hasil belajar dengan model pembelajaran ROPES (Review, Overview, Presentation, Exercise, Summary) dengan cara menghitung rata-rata nilai dan ketuntasan belajar secara klasikal.

Adapun rumus yang digunakan adalah:

1. Menghitung rata-rata nilai. Untuk menghitung rata-rata nilai klasikal digunakan rumus rata-rata nilai adalah :

$$
\mathrm{X}=\frac{\sum x}{N}
$$

(Arikunto, 2007: 264)

Keterangan:

$\mathrm{X}=$ Rata-rata nilai

$\sum x=$ Jumlah semua nilai siswa

$\mathrm{N}=$ Jumlah siswa

2. Menghitung ketuntasan belajar

a. Ketuntasan belajar individu

$$
\mathrm{S}=\frac{R}{N} \mathrm{x} 100
$$

(Purwanto, 2008) 
Keterangan :

S = Nilai yang dicari atau diharapkan

$\mathrm{R}$ = Skor yang diperoleh siswa

$\mathrm{N}=$ Skor maksimum dari tes

100 = Bilangan tetap

b. Ketuntasan belajar klasikal

Data diperoleh dari pengamatan hasil belajar dapat ditentukan ketuntasan belajar klasikal menggunakan analisis presentase dengan hitungan :

$$
\mathrm{P}=\frac{\text { Jumlah siswa yang tuntas }}{\text { jumlahsiswa }} \times 100 \%
$$

(Aqib dkk. 2009: 41)

Keterangan:

$\mathrm{P} \quad=$ Persentase ketuntasan belajar

$100 \%=$ Bilangan tetap

Tabel 1. Kriteria Penafsiran Presentase Ketuntasan Belajar

\begin{tabular}{cc}
\hline Persentase $(\mathrm{P}) \%$ & Kriteria \\
\hline$\geq 80$ & Sangat Baik \\
\hline $60-79$ & Baik \\
\hline $40-59$ & Cukup \\
\hline $20-39$ & Kurang \\
\hline$<20$ & Sangat Kurang \\
\hline
\end{tabular}

3. Data keaktifan siswa

Perhitungan presentase keaktifan siwa dalam mengikuti proses belajar sebagai berikut :

$$
\mathrm{NP}=\frac{R}{S M} x 100
$$

(Kunandar, 2014: 130)

Keterangan :

$\mathrm{NP}=$ Nilai aktivitas siswa

$\mathrm{R}=$ Skor yang diperoleh tiap siswa

$\mathrm{SM}=$ Skor maksimum dari kriteria yang ditentukan

$100=$ Bilangan tetap 
Tabel 2. Kriteria Penafsiran Nilai Aktivitas Belajar Siswa

\begin{tabular}{cc}
\hline Nilai Aktivitas Siswa (NP) & Kriteria \\
\hline$>80$ & keaktifan siswa sangat tinggi \\
\hline $66-80$ & keaktifan siswa tinggi \\
\hline $51-65$ & keaktifan siswa sedang \\
\hline$\leq 50$ & keaktifan siswa rendah \\
\hline$<20$ & Sangat Kurang \\
\hline
\end{tabular}

\section{Data kinerja guru}

Untuk mengetahui seberapa kinerja guru dalam melaksanakan pengajaran. Analisis ini dilakukan pada lembar observasi dengan menggukan teknik diskriptif melalui presentase :

$$
\mathrm{NK}=\frac{T S}{S M} x 100 \%
$$

(Aqib dkk, 2009: 41)

Keterangan :

NK = Nilai kinerja guru

TS = Total skor yang diperoleh guru

$\mathrm{SM}=$ Total skor maksimum dari aspek yang diamati

$100 \%=$ Bilangan tetap

Tabel 3. Kriteria Penafsiran Nilai Kinerja Guru

\begin{tabular}{cl}
\hline Nilai Kinerja Guru (NK) & \multicolumn{1}{c}{ Kriteria } \\
\hline $81-100$ & Kinerja guru sangat baik $(\mathrm{A})$ \\
\hline $61-80$ & Kinerja guru Baik $(\mathrm{B})$ \\
\hline $41-60$ & Kinerja guru Cukup $(\mathrm{C})$ \\
\hline $21-40$ & Kinerja guru Kurang (K) \\
\hline $81-100$ & Kinerja guru sangat baik $(\mathrm{A})$ \\
\hline
\end{tabular}

\section{HASIL DAN PEMBAHASAN}

Pembahasan hasil penelitian yang diuraikanberdasarkan atas hasil pengamatan yang dilanjutkan dengan refleksi pelaksanaan pembelajaran dengan menggunakan model ROPES (Review, overview, presentation, exercise, summary)pada tahap siklus I dan siklus II, serta tahap pra siklus sebagai pra penelitian.

Dari data prosentase ketuntasan belajar klasikal hasil belajar siswa hanya 53,12\%, dengan rata-rata hasil belajar 64,90 juga belum memenuhi indikator keberhasilan yang ditentukan yaitu $\leq 70 \%$. Sehingga pembelajaran model ROPES pada siklus I belum 
maksimal, maka harus dilaksanakan lagi pada siklus II. Berdasarkan hasil yang diperoleh masih ada beberapa kekurangan antara lain:

a. Guru belum maksimal dalam mengadakan pendahuluan dalam belajar mengajar untuk memasuki pembelajaran dengan model ROPES yang membutuhkan persiapan khusus agar siswa berminat dan bersemangat dalam melakukan proses belajar mengajar.

b. Berdasarkan hasil pengamatan siswa terhadap pelaksanaan siklus I, siswa kurang sigap dalam membentuk kelompok karena belum terbiasa dengan pembelajaran kelompok. Ada sebagian siswa yang masih gonta-ganti formasi, ada yang merasa tidak cocok dengan kelompoknya sehingga pembelajaran belum bisa berjalan sesuai yang direncanakan.

c. Siswa masih kurang aktif dan kurang berani dalam bertanya maupun menjawab pertanyaan dari guru dan teman-temanya sendiri.

d. Siswa masih belum maksimal dalam menyimpulkan dan mempresentasikan hasil diskunya.

Berdasarkan hasil pembelajaran pada siklus I dapat dilihat pada tabel berikut:

Tabel 4. Hasil Belajar Siswa Siklus I

\begin{tabular}{lcc}
\hline \multicolumn{1}{c}{ Siklus } & Pertemuan 1 & Pertemuan 2 \\
\hline Aktivitas Siswa & $59.67 \%$ & $66.01 \%$ \\
\hline Aktivitas Kinerja Guru & $60 \%$ & $70 \%$ \\
\hline Ketuntasan Belajar Klasikal & $53.12 \%$ & $53.12 \%$ \\
\hline
\end{tabular}

Pencapaian aktivitas siswa di siklus II ini mencapai $81,15 \%$. Hasil ini sudah lebih mencapai indikator keberhasilan yaitu > 75\%. Pembelajaran dengan menggunakan model ROPES sudah berhasil dan sudah menunjukkan peningkatan dari siklus I. Sedangkan aktivitas guru dalam siklus II ini pun mengalami kenaikan dari siklus I yaitu mencapai $80 \%$.

Data hasil belajar siswa siklus II, dapat diperoleh rata-rata hasil belajar siswa 73,18, dari 32 siswa ada 26 siswa yang tuntas yang nilainya $\geq 65$. Prosentase ketuntasan belajar klasikal hasil belajar yang dicapai siswapada siklus II adalah sebagai berikut:

$$
\begin{aligned}
\% \mathrm{P} & =\frac{\sum \text { siswa yang tuntas } \geq 65}{\sum \text { siswa }} \times 100 \% \\
\% \mathrm{P} & =\frac{26}{32} \times 100 \% \\
& =81 \%
\end{aligned}
$$


Dari data yang telah ada, prosentase ketuntasan belajar klasikal hasil belajar yang dicapai siswa pada siklus II sudah mencapai indikatorkeberhasilan yang ditentukan. Pembelajaran dengan menggunakan model ROPES pada siklus II sudah berhasil maka pembelajaran dengan model ROPES dicukupkan sampai siklus II.

Berdasarkan hasil pengamatan yang didapatkan pada kegiatan pembelajaran siklus II sudah berjalan sesuai rencana. Kekurangan-kekurangan pada siklus I sudah bisa teratasi di siklus II. Berdasarkan pengamatan kegiatan pembelajaran di siklus II adalah sebagai berikut:

Melihat hasil pada siklus II ini, dengan demikian hipotesis tindakan dan indikator keberhasilan dapat tercapai sehingga tidak perlu dilakukan berikutnya. Berdasarkan datadata diatas maka bisa disimpulkan bahwa penggunaan model pembelajaran ROPES di kelas VII B siswa MTs Matholiul Ulum Banjaragung tahun pelajaran Bangsri Jepara tahun pelajaran 2019/2020 pada pokok bahasan Persamaan Linier ivir

Pelaksanaan siklus II mengalami peningkatan pada aktivitas siswa mencapai $81,15 \%$, aktivitas guru $80 \%$, ketuntasan belajar klasikal $81 \%$ dan rata-rata hasil belajar mencapai 73,18\%. Keberhasilan siklus II karena siswa sudah mulai aktif dan memahami konsep model pembelajaran ROPES.

Tabel 5. Perbandingan Hasil Belajar Siswa Siklus I dan Siklus II

\begin{tabular}{|c|c|c|c|}
\hline \multirow{2}{*}{ Kegiatan } & \multicolumn{2}{|c|}{ Siklus I } & \multirow{2}{*}{ Siklus II } \\
\hline & 1 & 2 & \\
\hline Aktivitas Siswa & $59.67 \%$ & $66.01 \%$ & $81.15 \%$ \\
\hline Aktivitas Guru & $60 \%$ & $70 \%$ & $80 \%$ \\
\hline Ketuntasan Belajar Klasikal & \multicolumn{2}{|c|}{$53.12 \%$} & $81 \%$ \\
\hline Rata-rata Hasil Belajar & \multicolumn{2}{|c|}{$64.90 \%$} & $73.18 \%$ \\
\hline
\end{tabular}

Dari tabel di atas terlihat jelas bahwa setiap siklus dari siklus I ke siklus II mengalami peningkatan pada aktivitas siswa, aktivitas guru, ketuntasan belajar klasikal dan rata-rata hasil belajar siswa. Hal ini menunjukkan bahwa penggunaan model pembelajaran ROPES (Review, overview, presentation, exercise summary) tepat digunakan pada materi pokok persamaan linier satu variabel pada siswa kelas VII B MTs Matholiul Ulum Banjaragung Bangsri Jepara tahun pelajaran 2019/2020. 


\section{SIMPULAN DAN SARAN}

Berdasarkan perumusan masalah analisis data penelitian dan hasil pembahasan penelitian maka dapat disimpulkan bahwa pembelajaran matematika dengan menggunakan model pembelajaran ROPES pada pembelajaran matematika dapat meningkatkan hasil belajar siswa kelas VII B MTs. Matholiul Ulum Banjaragung Bangsri Jepara tahun pelajaran 2019-2020.

Hal tersebut dapat diketahui dari: 1) Meningkatnya prosentase ketuntasan belajar siswa pada siklus I dari $53 \%$ menjadi $81 \%$ pada siklus II, dan nilai rata-rata siswa dari siklus I sebesar 64,90 pada siklus II menjadi 73,18.

1. Meningkatnya keaktifan siswa

Siklus I pertemuan pertama dengan prosentase 59,67\%, siklus I pertemuan kedua $66,01 \%$, dan siklus II pertemuan pertama dengan prosentase $81,15 \%$.

2. Hasil prosentase kinerja guru dalam pembelajaran ROPES.

Siklus I pertemuan pertama denganprosentase $60 \%$, siklus I pertemuan kedua dengan prosentase $70 \%$, dan siklus II pertemuan pertama denga prosentase $80 \%$.

3. Minat-minat hasil angket dari 32 siswa adalah 88,9\%, ini termasuk kategori sangat tinggi, sehingga secara klasikal minat siswa terhadap pembelajaran ROPES (Review. Overview, Presentation, Exercise, Summary) dikategorikan sangat tinggi.

\section{DAFTAR PUSTAKA}

Aqib, Zainal, dkk. 2009. Penelitan Tindakan Kelas Untuk Guru. Bandung: Yrama Widya. Arikunto, S. 2007. Penelitian Tindakan Kelas. Jakarta: Rineka Cipta.

Kunandar, 2014. Penilaian Autentik (Penilaian Hasil Belajar Peserta Didik Berdasarkan Kurikulum 2013). Jakarta: Raja GrafindoPersada.

Mulyana, Rahmat. 2004. Mengartikulasi Pendidikan Nilai. Bandung: Alfabeta.

Ningrum E. 2009. Penelitian Tindakan Kelas. Bandung: Buana Nusantara.

Purwanto, Ngalim, 2008. Prinsip-prinsip dan tekhnik Evaluasi Pengajaran. Bandung: PT Remaja Rosdakarya.

Sanjaya, W. 2010. Penelitian Tindakan Kelas. Jakarta: Kencana Prenada Media Group. 
Sumitro, Dwi S,dkk. 2006. Pengantar Ilmu Pendidikan. Yogyakarta: Fakultas Ilmu Pendidikan Universitas Negeri Yogyakarta. 